\title{
Pemahaman Membaca Mahasiswa Terhadap Artikel Bahasa Inggris Berbasis Web
}

\author{
Marginingsih $^{1}$, Anindhiasti Ayu Kusuma Asri ${ }^{2}$ \\ Program Studi Teknik Informatika - Universitas Duta Bangsa Surakarta \\ Email: nmargi344@gmail.com, anindhiaaayu@gmail.com
}

\begin{abstract}
Abstrak
Median koran sudah berkembang sedemikian cepatnya, dari media kertas menjadi media digital atau berbasis web. Tujuan dari penelitian ini adalah untuk membandingkan kemampuan membaca pemahaman mahasiswa program studi Teknik Informatika terhadap artikel bahasa Inggris berbasis web dari segi content and level of difficulty. Penelitian ini menginvestigasi perbedaan gender terhadap pemahaman membaca. Mahasiswa di minta membaca artikel dari The Jakarta Post, The Bali times dan the Jakarta Globe. Setelah itu mahasiswa mengisi kuesioner, menjawab soal essay dan makna kata dari artikel..

Jenis penelitian yang digunakan adalah mix-method. Penelitian ini menjelaskan pemahaman membaca artkel bahasa Inggris berbasis web pada mahasiswa berdasarkan kelompoknya. Pengumpulan data adalah survey kuesioner dan soal essay. Analisis data dilakukan melalui analisis hasil survey dan hasil jawaban mahasiswa. Hasil penelitian menunjukkan bahwa pria memperoleh nila rata-rata lebih tinggi dari wanita pada artikel dari Jakarta Post dan Jakarta Globe. Sedangkan wanita memperoleh nilai rata-rata lebih tinggi pada artikel dari Bali Times.
\end{abstract}

Kata kunci:Pemahaman Membaca, artikel, gender

\section{PENDAHULUAN}

Ketika mengajar bahasa asing, pengajar harus mampu menemukan materi yang sesuai dengan kemampuan mahasiswa. materi otentik adalah penting untuk digunakan ketika mengajar bahasa Ingris sebagai bahasa asing. Mahasiswa sebaiknya disiapkan untuk menggunakan bahasa Inggris dalam menghadapi berbagai situasi. Dalam silabus bahasa Inggris 1, tujuan membaca adalah mahasiswa dapat mempraktikan Reading comprehension yang mencakup berbagai genre dan tema bacaan, serta ide pokok (main idea) dalam sebuah bacaan, mempraktikan Reading comprehension yang mencakup pertanyaan detail,reference words (kata acuan), dan inference (kesimpulan) danvocabulary. Dari tujuan membaca pemahaman tersebut berarti mahasiswa sebaiknya membaca berbagai macam jenis teks yang salah satunya adalah dari artikel koran yang berbasis web.

Di Indonesia terdapat berbagai macam artikel koran berbasis web. Menurut http://www.onlinenewspapers.com terdapat sekitar 66 koran berbasis web yang tersebar di seluruh Indonesia, yang berbahasa Inggris ada 5 yaitu: Tempo Interactive, The Indonesian Observer,TheJakarta Post, The President
Post, SuratkabarCom Online. Sedangkan menurut https://En. wikipedia.org/wiki ada 3 koran berbahasa inggris di Indonesia yaitu The BaliTimes, The Jakarta Globe dan The Jakarta Post.

Berdasarkan latar belakang masalah tersebut diatas, dosen harus memilih materi dari artikel koran yang sesuai untuk proses pembelajaran. Penelitian akan menjelaskan pemahaman membaca mahasiswa dari 3 artikel koran yang berbeda. Faktor yang mempengaruhi pemahaman mahasiswa akan dianalisis dari jenis isi artikel dan tingkat kesukaran untuk mengetahui hubungan antara faktor-faktor tersebut dengan kemampuan pemahaman mahasiswa terhadap artikel koran dari segi gender.

\section{METODE PENELITIAN}

a. Kerangka kegiatan Penelitian

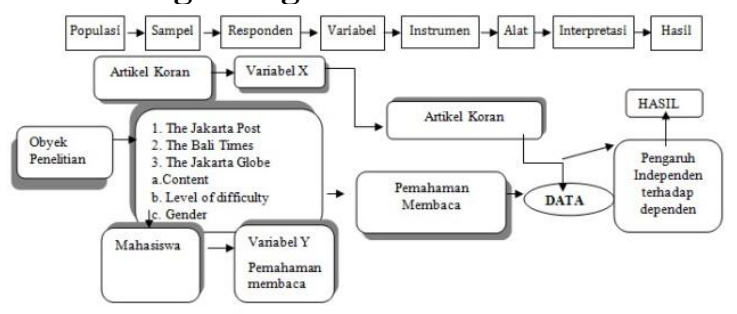


Gambar 1. Kerangka kegiatan penelitian

\section{b. Lokasi dan Obyek Penelitiann}

Penelitian ini dilaksanakan diProgram Studi Teknik Informatika Fakultas Ilmu Komputer Universitas Duta Bangsa Jl. Bhayangkara No.55 Surakarta. sedangkan obyek atau sample penelitian adalah mahasiswa semester II program studi Teknik Informatika. Populasi penelitian ini adalah seluruh mahasiswa program studi Teknik Informatika semester II tahun ajaran 2018/2019 Universitas Duta Bangsa Surakarta.

\section{c. Metode Pengumpulan Data}

Metode pengumpulan data yang dilakukan dalam penelitian ini adalah mixmethod yaitu tiga artikel dari tiga koran online. Materi dipilih dengan topik yang berbeda. Soal essay dan vocabulary diberikn kepada mahasiswa untuk mengetahui nilai rata-rata mahasiswa yang menjawab pertanyaan dengan benar setelah menjawab soal mahasiswa diberikan kuesioner untuk mengetahui nilai rata-rata mahasiswa berdasarkan gender, tingkat kesukaran terhadap artikel.

\section{TINJAUAN PUSTAKA}

\section{a. Pengertian Pemahaman Membaca}

Membaca merupakan proses aktif. Membaca melibatkan interaksi antara pembaca dan teks. Menurut Pearson, Rochler, Dole,dan Duffy (1992) pembaca yang baik selalu menggunakan keahlian dan strategi yaitu menggunakan pengetahuan sebelumnya untuk menghubungkan dengan pengetahuan baru, mempunyai pertanyaan tentang teks sebelum, sedang dan setelah membaca, menarik kesimpulan dari teks, menebak kata, menemukan gagasan utama dan menyimpulkan informasi.

Demikian juga pendapat dari Johnson et al., (2004:3) bahwa pemahaman membaca adalah proses aktif, diarahkan oleh pemikiran yang disengaja yang memungkinkan pembaca untuk menghubungkan antara proses berpikir, isi teks, dan pengetahuan mereka sendiri, harapan dan tujuan untuk membaca. Kemampuan pemahaman siswa akan membimbing mereka untuk memahami teks, mereka akan mendapatkan informasi, baik informasi yang secara jelas dinyatakan atau informasi yang tidak ditulis dalam teks.
Ada beberapa teori tentang pentingnya kemampuan membaca dan bagaimana mengimplementasikan di kelas. Extensive reading adalah salah satu istilah yang digunakan pembelajaran bahasa terutama teks membaca selain dari buku. Hedge (2000:202)defines extensive reading and also describes various types of extensive reading. It can mean reading large quantities of material, reading consistently over time on a frequent basis,combination reading longer texts in class with individual reading at home. Short stories, novels, newspaper articles and magazine articles are some of the reading sources.

Ketika memilih teks bacaan harus mempertimbangkan kemampuan dan minat mahasiswa (Ericsson, 1989:247). Sedangkan Hedge mengatakan bahwa: When the teacher use text for the students, they must consider a variety of topics, length of text and reading purpose. Magazine articles and news articles can be used to curiosity about a topic and in order to know what is happening in the world (Hedge, 2000:207).

\section{b. Perbedaan Gender}

Penelitian sudah banyak dilakukan pada perbedaan gender. The Gendered Society oleh the American Michael S. Kimmel telah meneliti situasi sekolah di Amerika. Dia mengatakan bahwa :

"The interplanetary theory of gender tells us that boys and girls are basically different. Boys are good at science and math, play violently, and shout out in class. Girls, on the other hand sit quietly, speak softly, play gingerly, and good at French and literature" (Kimmel, 2004:159).

Nickie Charles menjelaskan di Gender in Modern Britain bahwa sekolah adalah dunia wanita (Bjornsson, 2005). Penelitian menunjukkan bahwa " There is a change of girls' behaviour. They are now speak up. While, boys seem to stay in a more traditional and unchanged gender identity. If boys are serious in their school, their heterosexuality might be questioned. A girl seems to do well in school easier and be more popular than boys. Departemen pendidikan Swedia 2004 menyatakan tentang perbedaan gender bahwa perempuan memperoleh nilai rata-rata lebih tinggi daripada pria dan banyak pria tidak 
lulus pada pelajaran bahasa inggris, bahasa swedia dan matematika.

\section{HASIL DAN PEMBAHASAN}

a. Analisis Artikel Koran Berbasis Web.

Tiga artikel dari Jakarata Post, Jakarta Globe dan Bali Times berbeda isi dan tingkat kesulitannya. Tujuan dari variasi artikel untuk memberikan gambaran yang menyeluruh kemampuan pemahaman membaca mahasiswa.

\section{1) Jakarta Post.}

Jakarta post adalah sebuah harian berbahasa Inggris di Indonesia. Jakarta post memiliki edisi minggu (Sunday) dan Daring (online) yang isinya tidak di terbitkan di edisi cetak harian. Artikel dari jakarta post edisi Daring yang diambil adalah "Indonesia without feminists group starts online campaign". Artikel ini terbit tangal 2 April 2019. Isi dari artikel ini tentang kelompok gerakan Indonesia Tanpa Feminis berkampanye lewat media sosial seperti instagram dan hashtags. Gerakan ini menimbulkan pro dan kontra. Pendapat masyarakat yang pro mengatakan bahwa gerakan ini melindungi wanita antifeminisme dari tindak kekerasan di tempat kerja khususnya. Sementara pendapat yang kontra mengatakan bahwa gerakan ini merupakan gerakan anti nilai Islam,salah menafsirkan kata feminim, dan mendukung kelompok LGTB. Bahasa dari artikel ini koheren.Informasi yang disampaikan berkesinambungan. Namun banyak kosakata yang sulit dan kalimatnya panjang dan komplex.

\section{2) Jakarta Globe}

Jakarta Globe adalah koran online harian berbahasa Inggris terbit senin sampai sabtu. Sasaran pembacanya adalah warga kosmopolitan, orang berpendidikan dan warga asing. Artikel yang diambil terbit pada tanggal 22 Maret 2019. Artikel ini dengan judul 'Indonesia consider ban on PUBG. Ini tentang larangan game PUBG oleh menteri teknologi telekomunikasi dan informasi karena adanya fatwa Ulama Jawa barat. Game ini penuh dengan kekerasan sehingga memicu gerakan teroris yang menewaskan 50 orang. Bahasa yang digunakan dari artikel ini cukup rumit, panjang, dan menggunakan kalimat tidak langsung.

\section{3) Bali Times}

Bali times adalah koran harian berbahasa Ingris yang ada di Bali. Ini berisi berita tentang Bali, berita nasional dan internasional, bisnis, olah raga, kesehatan dan lain-lain. Artikel yang diambil terbit pada tanggal 8 Januari 2019. Artikel ini dengan judul "Bali ombudsman recommends standardization to cope with cheap tourism". Secara garis besar artikel ini tentang standarisasi biaya turis untuk tujuan Bali. Standarisasi dari segi operator wisata, biaya akomodasi dan konsumsi, dan pelayanan budaya. Dengan adanya standarisasi akan meminimalis paket wisata murah dan citra yang bagus tentang pulau dewata tetap terjaga. Bahasa dari artikel cukup mudah dipahami, banyak menggunakan kalimat langsung.

\section{b. Perbedaan Jenis Kelamin \\ 1) Jakarta Post- 'Indonesia without feminists group starts online campaign'}

Perempuan memperoleh nilai rata-rata 3 menjawab pertanyaan dengan benar. Pria memperoleh nilai rata-rata 3.52 yang menjawab pertanyaan dengan benar.

Tabel 1. Hasil rata-rata pertanyaan essay

\begin{tabular}{|c|c|c|}
\hline $\begin{array}{c}\text { Pertanyaan essay yang } \\
\text { dijawab dengan benar }\end{array}$ & Wanita & Pria \\
\hline Rata rata & $3 \%$ & 3.52 \\
\hline
\end{tabular}

Kebanyakan wanita menjawab 3- 4 kata dari 10 kosakata yang diberikan. Sedangkan pria mampu menjawab 4-6 soal dengan benar.

Tabel 2. Hasil rata-rata kosakata

\begin{tabular}{|c|c|c|}
\hline $\begin{array}{c}\text { Kosakata yang dijawab } \\
\text { dengan benar }\end{array}$ & Wanita & Pria \\
\hline Rata-rata & 4.6 & $5.4 \%$ \\
\hline
\end{tabular}

Kebanyakan dari wanita dan pria menyatakan bahwa artikel tersebut sulit.

Tabel 3. Hasil rata-rata tingkat kesulitan

\begin{tabular}{|l|l|l|}
\hline Tingkat Kesulitan & Wanita & Pria \\
\hline Sulit & $45 \%$ & $60 \%$ \\
\hline Mudah & $55 \%$ & $40 \%$ \\
\hline
\end{tabular}

\section{2) Jakarta Globe- 'Indonesia consider ban on PUBG'}

Perempuan memperoleh nilai rata-rata 3.4 menjawab pertanyaan dengan benar. Pria memperoleh nilai rata-rata 3.6 yang menjawab pertanyaan dengan benar.

Tabel 4. Hasil rata-rata pertanyaan essay

\begin{tabular}{|l|c|c|}
\hline $\begin{array}{c}\text { Pertanyaan essay yang } \\
\text { dijawab dengan benar }\end{array}$ & Wanita & Pria \\
\hline
\end{tabular}




\begin{tabular}{|c|c|c|}
\hline Rata rata & $3.4 \%$ & $3.6 \%$ \\
\hline
\end{tabular}

Kebanyakan wanita menjawab 3- 4 kata dari 10 kosakata yang diberikan. Sedangkan pria mampu menjawab 4-6 soal dengan benar.

Tabel 5. Hasil rata-rata kosakata

\begin{tabular}{|c|c|c|}
\hline $\begin{array}{c}\text { Kosakata yang } \\
\text { dijawab dengan benar }\end{array}$ & Wanita & Pria \\
\hline Rata-rata & $4.4 \%$ & $4.95 \%$ \\
\hline
\end{tabular}

Kebanyakan dari wanita dan pria menyatakan bahwa artikel tersebut sulit.

Tabel 6. Hasil rata-rata tingkat kesulitan

\begin{tabular}{|c|c|c|}
\hline $\begin{array}{c}\text { Tingkat Kesulitan } \\
\text { artikel }\end{array}$ & Wanita & Pria \\
\hline Sulit & $60 \%$ & $65 \%$ \\
\hline Mudah & $40 \%$ & $35 \%$ \\
\hline
\end{tabular}

3) Bali Times- 'Bali ombudsman recommends standardization to cope with cheap tourism'

Perempuan memperoleh nilai rata-rata 3.9 menjawab pertanyaan dengan benar. Pria memperoleh nilai rata-rata 3.4 yang menjawab pertanyaan dengan benar.

Tabel 7. Hasil rata-rata pertanyaan essay

\begin{tabular}{|c|c|c|}
\hline $\begin{array}{c}\text { Pertanyaan essay yang } \\
\text { dijawab dengan benar }\end{array}$ & Wanita & Pria \\
\hline Rata rata & $3.9 \%$ & $3 \%$ \\
\hline
\end{tabular}

Kebanyakan wanita menjawab 4-5 kata dari 10 kosakata yang diberikan. Sedangkan pria mampu menjawab 5- 7 soal dengan benar.

Tabel 8.Hasil rata-rata kosakata

\begin{tabular}{|c|c|c|}
\hline $\begin{array}{c}\text { Kosakata yang dijawab } \\
\text { dengan benar }\end{array}$ & Wanita & Pria \\
\hline Rata-rata & $5.3 \%$ & $4 \%$ \\
\hline
\end{tabular}

Kebanyakan dari wanita dan pria menyatakan bahwa artikel tersebut sulit.

Tabel 9.Hasil rata-rata tingkat kesulitan

\begin{tabular}{|c|c|c|}
\hline $\begin{array}{c}\text { Tingkat Kesulitan } \\
\text { artikel }\end{array}$ & Wanita & Pria \\
\hline Sulit & $70 \%$ & $75 \%$ \\
\hline Mudah & $30 \%$ & $25 \%$ \\
\hline
\end{tabular}

Dari hasil test essay dan menterjemahkan kosa kata dari artikel bahasa Inggris Bali Times dengan tema wisata, wanita memperoleh nilai rata-rata lebih tinggi dibanding pria. Sedangkan pria memperoleh nilai rata-rata lebih tinggi dari pria pada artikel Jakarta post dengan tema politik dan artikel Jakarta Globe dengan tema game. Sedangkan, dari hasil kuisioner tentang tingkat kesulitan artikel apakah artikel itu mudah atau sulit, kebanyakan responden wanita dan pria menyatakan bahwa artikel tersebut sulit.

\section{KESIMPULAN DAN SARAN \\ a. Kesimpulan}

Berdasarkan penelitian tentang pemahamanan membaca mahasiswa berbasis web, maka dapat disimpulkan sebagai berikut:

1) Mahasiswa pria memperoleh nilai rata-rata lebih tinggi dibandingkan wanita.

2) Perbedaan gender tidak sama dengan penelitian sebelumnya dimana dalam penelitian ini pria menjawab soal dan menterjemahkan kosakata dari artikel lebih baik dibanding wanita.

3) Dari tingkat kesulitan artikel, kebanyakan responden menyatakan konten bacaan sulit untuk dipahami

\section{b. Saran}

Penelitian ini jauh dari kesempurnaan. Namun peneliti memberi saran sebagai berikut:

1) Responden dari penelitian ini adalah mahasiswa, maka perlu diberikan materi reading comprehension dari artikel bahasa Inggris berbasis web yang mudah diakses kapanpun dalam proses pembelajaran.

2) Penelitian ini mengambil data dari 3 koran bahasa Inggris berbasis web. Bagi dosen bahasa Inggris tidak hanya mengakses dari 3 koran tersebut tapi juga bisa mengakses artikel lainnya.

3) Ketika mengajar mahasiswa dikelas, sebaiknya dosen tidak membedakan gender karena mereka mempunyai hak yang sama untuk mendapatkan pendidikan.

\section{REFERENSI}

Arikunto, 2006, Prosedur Penelitian Suatu Pendekatan Praktik, Edisi Revisi VI, Rineka cipta, Jakarta

Hedge, Tricia. 2000. Teaching and Learning in the Language Classroom

https://www.collinsdictionary.com/dictionary/ english/synergy

hhtps.//www.Jakartapost.com

https://www.Jakartaglobe.id 
http://www.onlinenewspapers.com/indonesia.h tml

https://www.thebalitimes.com

https:

//En.Wikipedia.org/wiki/list_of_News paper_in_Indonesia

Johnson, E.B.2004. (2004). Comprehension Process Instruction: Creating Reading success in grades $K-3$. New York, NY: The Guilford Press
Jörnsson, Mats. 2005 Kön och skolframgång Tolkningar och perspektiv. Stockholm:Liiber

Kimmel, Michael S. 2004 The Gendered Society. 2nd edition. New York: Oxford University Press .

I. Pearson, et.al. 1992. Developing Expertise in Reading Comprehension. New York. McGraw-Hill, Inc. 